\title{
Economic Recovery of Oil Trapped at Fan Margins Using High Angle Wells and Multiple Hydraulic Fractures
}

\author{
Quarterly Report \\ October 1 - December 31, 1997
}

\author{
By: \\ Mike L. Laue
}

Work Performed Under Contract No.: DE-FC22-95BC14940

\author{
For \\ U.S. Department of Energy \\ Office of Fossil Energy \\ Federal Energy Technology Center \\ P.O. Box 880 \\ Morgantown, West Virginia 26507-0880
}

By

Atlantic Richfield Company

P. O. Box 147

Bakersfield, California 93302 


\section{Disclaimer}

This report was prepared as an account of work sponsored by an agency of the United States Government. Neither the United States Government nor any agency thereof, nor any of their employees, makes any warranty, express or implied, or assumes any legal liability or responsibility for the accuracy, completeness, or usefulness of any information, apparatus, product, or process disclosed, or represents that its use would not infringe privately owned rights. Reference herein to any specific commercial product, process, or service by trade

name, trademark, manufacturer, or otherwise does not necessarily constitute or imply its endorsement, recommendation, or favoring by the United States Government or any agency thereof. The views and opinions of authors expressed herein do not necessarily state or reflect those of the United States Government or any agency thereof. 
TITLE: ECONOMIC RECOVERY OF OIL TRAPPED AT FAN MARGINS USING HIGH ANGLE WELLS AND MULTIPLE HYDRAULIC FRACTURES

Cooperative Agreement No.: $\quad$ DE-FC22-95BC14940--11

Contractor Name and Address: $\quad$ Atlantic Richfield Co., P.O. Box 147, Bakersfield, California 93302

Date of Report: $\quad$ February 5, 1998

Award Date: $\quad$ September 28, 1995

Anticipated Completion Date: $\quad$ September 28, 2001

Government Award for

Current Fiscal Year: $\quad \$ 3,926,267$

Principal Investigator: Mike L. Laue, ARCO

Project Manager: $\quad$ Edith Allison, Bartlesville Project Office

Reporting Period: $\quad$ Oct. 1-Dec. 31, 1997

\section{Disclaimer}

This report was prepared as an account of work sponsored by an agency of the United States Government. Neither the United States Government nor any agency thereof, nor any of their employees, makes any warranty, express or implied, or assumes any legal liability or responsibility for the accuracy, completeness, or usefulness of any information, apparatus, product, or process disclosed, or represents that its use would not infringe privately owned rights. Reference herein to any specific commercial product, process, or service by trade name, trademark, manufacturer, or otherwise does not necessarily constitute or imply its endorsement, recommendation, or favoring by the United States Government or any agency thereof. The views and opinions of authors expressed herein do not necessarily state or reflect those of the United States Government or any agency thereof.

\section{Objective}

This project attempts to demonstrate the effectiveness of exploiting thin-layered, lowenergy deposits at the distal margin of a prograding turbidite complex through the use of hydraulically fractured horizontal or high-angle wells. The combination of a horizontal or high-angle well and hydraulic fracturing will allow greater pay exposure than can be achieved with conventional vertical wells while maintaining vertical communication between thin interbedded layers and the wellbore.

A high-angle well will be drilled in the fan-margin portion of a slope-basin clastic reservoir and will be completed with multiple hydraulic-fracture treatments. Geologic modeling, reservoir characterization, and fine-grid reservoir simulation will be used to 
select the well location and orientation. Design parameters for the hydraulic-fracture treatments will be determined, in part, by fracturing an existing test well. Fracture azimuth will be predicted by passive seismic monitoring of a fracture-stimulation treatment in the test well using logging tools in an offset well.

\section{Summary of Technical Progress}

The long radius, near horizontal well has been drilled. Well conditions dictated that a 5 in. production liner, in addition to the originally-planned $7 \mathrm{in}$. production liner, were necessary to case the target formation.

Swept-out sand intervals and a poor cement bond behind the 5 in. liner precluded two of the three originally planned hydraulic fracture treatments. All pay intervals behind the 5 in. liner were therefore perforated and stimulated with a non-acid reactive fluid.

Following a short production period, the remaining pay intervals in the well, behind the $7 \mathrm{in}$. liner, were then perforated. The well was returned to production to observe production trends and pressure behavior prior to stimulation of the newer perforations.

\section{Completion Operations}

\section{Production Performance}

Yowlumne Unit B 91X-3 was originally completed by perforating all pay intervals behind the 5 in. production liner. This primarily included Sand $\mathrm{C}$ and a small interval at the base of Sand B (Fig. 1). The perforations were then stimulated with a non-acid reactive fluid consisting of a blend of $\mathrm{KCl}$ water, iron chelating agents, mutual solvents, and surfactants.

The initial production rate was $220 \mathrm{BOPD}$ and $20 \mathrm{BWPD}$. However, in less than two and one-half months oil production had declined to $160 \mathrm{BOPD}$, and water cut had increased to $35 \%$ (Fig. 2). The gas-oil ratio (GOR) remained fairly constant at 450 SCF gas per STB oil.

\section{Additional Wellwork}

Because of production decline, additional pay intervals were perforated. This represented Sands A and B, behind the 7 in. production liner (Fig. 1).

The well was returned to production without stimulation. The initial production rate was approximately 230 BOPD. However, after a month and a half the well had declined to $160 \mathrm{BOPD}$, same as the pre-wellwork rate (Fig. 2).

The producing water cut of $43 \%$ is slightly higher than before. The biggest change though was the GOR, which increased from 450 SCF/STB to 1200 SCF/STB. 


\section{$\underline{\text { Future Plans }}$}

The new perforations will be stimulated with a similar non-acid system as that used on the original perfs. The well will be returned to production for a clean up period and to observe production trends and pressure behavior.

A hydraulic fracture treatment will then be designed for Sands A and B (through the new perfs in the 7 in. production liner).

\section{Technology Transfer}

Dr. Mike Clark gave a talk with abstract on the reservoir characterization aspect of this project on November 11, 1997 at the Pacific Coast Oil Show in Bakersfield, California. 


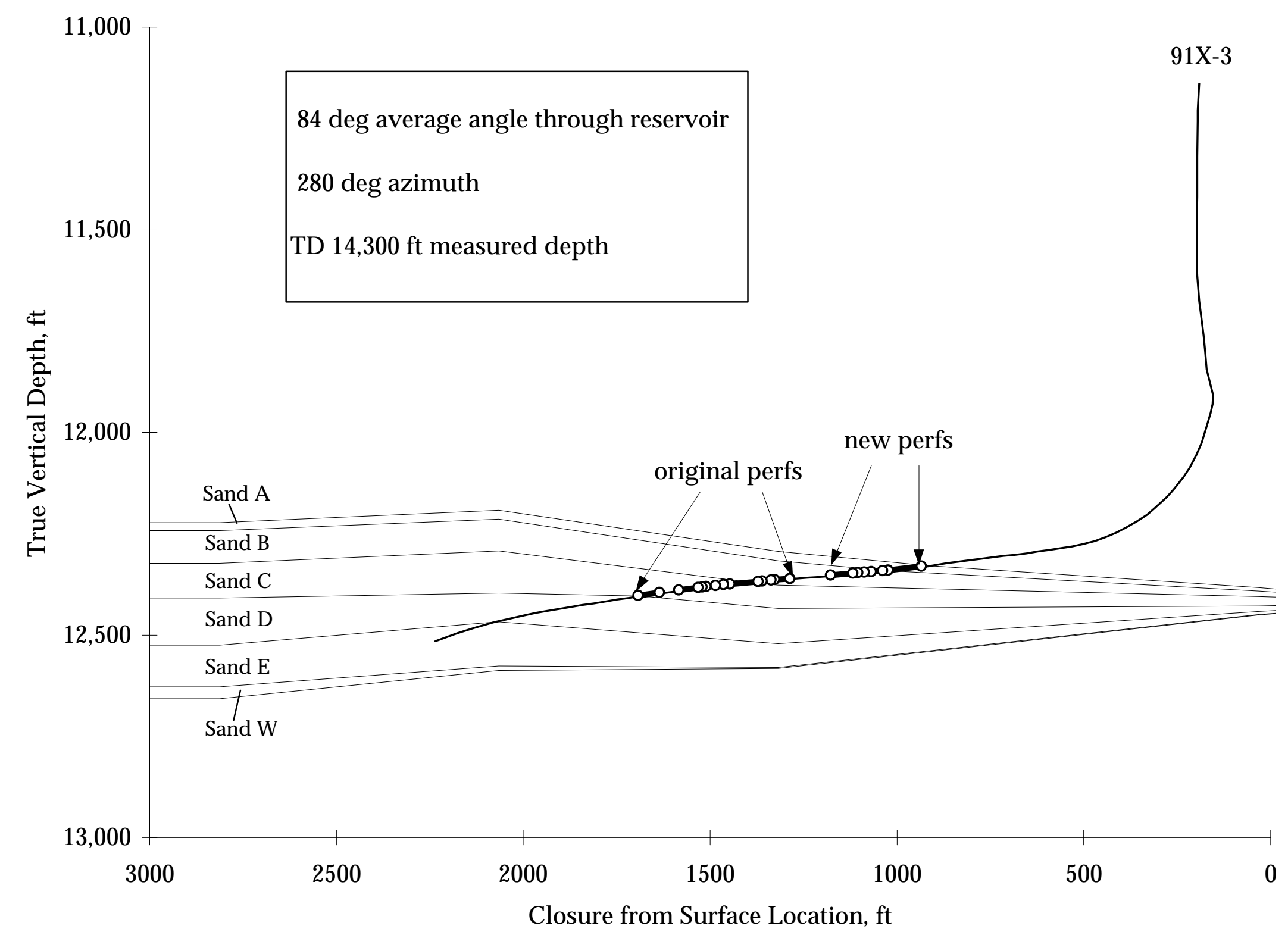

Figure 1. Actual well path relative to major Yowlumne sand intervals. Also shown are existing perforated intervals. 


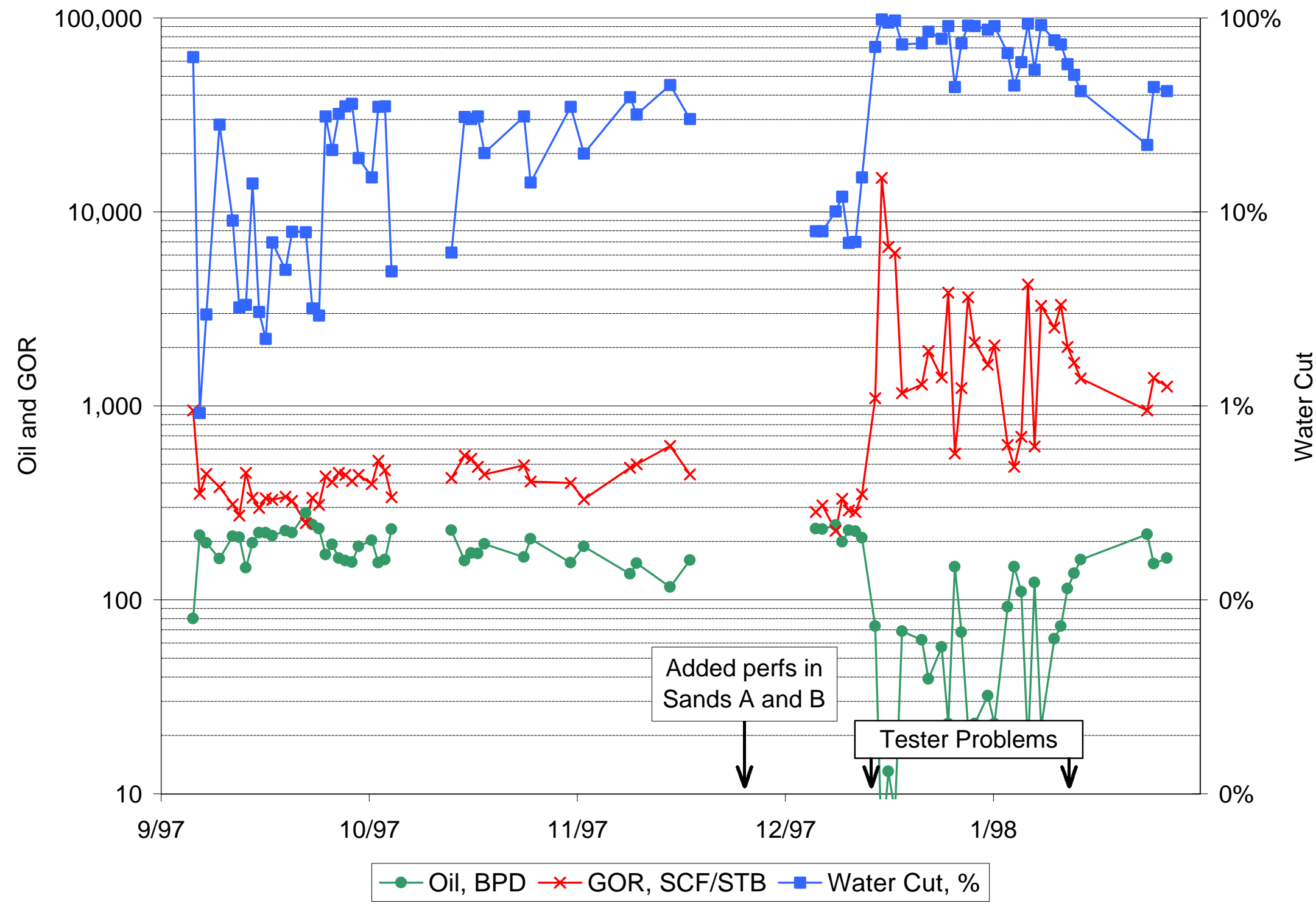

Figure 2. Well tests for Yowlumne Unit B 91X-3. 